\title{
Training Needs of Tribal Farm Women in Dairy Farming in Eastern Rajasthan
}

\author{
Bacchu Singh $^{1^{*}}$, Deepa Indoria ${ }^{2}$, K. C. Meena ${ }^{3}$ and G. S. Meena ${ }^{4}$ \\ ${ }^{1}$ Krishi Vigyan Kendra, Hindaun ( Karauli), Agriculture University Kota, India \\ ${ }^{2}$ Krishi Vigyan Kendra, Chittorgarh, MPUA\&T, Udaipur, India \\ ${ }^{3}$ College of Agriculture, Agriculture University, Kota, India \\ ${ }^{4}$ Krishi Vigyan Kendra, Bundi, Agriculture University Kota, India \\ *Corresponding author
}

\section{A B S T R A C T}

Keywords

Training needs, Tribal farm women, Dairy farming

Article Info

Accepted:

26 April 2020

Available Online:

10 May 2020
This study was conducted in the Karauli district of Rajasthan to assess the training needs of farmwomen engaged in dairy farming. It was found that the out of the five major farm operations studied, the farm women needed training the most in housing. The minor operations preferred the most for knowledge need were proper design of cattle shed, selection of breeds, compounding balanced feed using locally available ingredients, vaccination and banking and insurance. As for skill need, Construction of scientific low cost cattle shed, selection of breeds, compounding balanced feed using locally available ingredients, symptoms of common diseases and banking and insurance were preferred the most.

\section{Introduction}

The contribution of farmwomen in agriculture is likely to be around fifty to sixty percent. Women play an important role in animal husbandry activities as manager, decision makers and skilled workers. Most of the work involving livestock management is considered as the traditional responsibility of women. The feeding, cleaning and milking of dairy animals, the care of young animals, and administration of medicines are done mostly by women. Under such conditions, dairying constitutes an important activity of the rural population, mostly a subsidiary occupation.

Women are the prime decision makers in dairy production activities such as utilization of milk, care of pregnant animals and calves, brining of fodder and feeding of concentrate. In Rajasthan, agricultural and livestock management operations are generally 
performed by farm women. She cleans the animals and animal shed, arranges feed and water for them. Dairying has become an important secondary source of income for millions of rural families and has assured the most important role in providing employment and income generating opportunities particularly for women farmers. Rajasthan has about $6.09 \%$ of country's cattle population and contributes over $10 \%$ of total milk production.

Dairying is one of the important enterprises, which supports the rural households by providing gainful employment and steady income. The importance of milk and milk products for the physical development and well-being of human beings is universally recognized. In India, women's involvement in livestock management is a longstanding tradition and dairy farming has been an integral part of homestead farming system.

Although much of the work related to livestock farming is carried out by women, the areas in which they need training the most are not given due consideration while designing training programmes. Hence the studies on accessing the training needs of farm women engaged in dairy farming are of paramount importance to the extension agencies involved in rural development. So, the study has been undertaken withan objective to understand the training needs of farmwomen engaged in dairy farming.

\section{Materials and Methods}

The present study was conducted in Karauli district of Rajasthan. The investigation was concerned with SARAS dairy which is the largest milk collecting union in Eastern Rajasthan. The head office of SARAS is situated at Hindaun City. Out of the 30 milk co-operative societies of two purposively randomly selected blocks of Karauli namely;
Hindaun and Karauli, 10 milk co-operative societies were randomly selected for this study. Further, total 100 member respondents were selected from the 10 milk cooperative societies by stratified random sampling procedure using proportional allocation. Data were collected by personal interviews using a pre-tested structured schedule. The training need index for each of the major farm operation was calculated using the formula.

\section{Results and Discussion}

Table 1 revealed housing as the most preferred major farm operation followed by feeding and management for both knowledge and skill based training. The farm operations relating to housing, feeding and management were usually done by the farm women. This might be the reason for the farm women preferring housing and feeding and management as important training areas. The finding is in agreement with that of Sumathi and Alagesan (2001) who found that cent percent of the respondents needed training in maintenance of cattle shed.

Madivanane (1990) also found that maintenance of cattle shed ranked as second for getting training in livestock keeping. Since the major farm operations of breeding, health care and marketing and finance require outside contact the involvement of farm women was less. This might be the reason for the farm women to perceive these major farm operations as the least preferred areas of training. From table 2 it could be found that under housing, the farm women needed training the most on proper design of cattle shed for knowledge and construction of scientific low cost cattle shed for skill.

It is worth mentioning the finding that the farm women perceived proper design of cattle shed for knowledge training and construction of cattle shed for skill training. 
Table.1 Training needs pertaining to the major farm operations in dairy farming for knowledge and skill

\begin{tabular}{|l|l|c|c|c|c|}
\hline S.No. & \multirow{2}{*}{ Major Farm Operations } & \multicolumn{2}{|c|}{ Knowledge } & \multicolumn{2}{|c|}{ Skill } \\
\cline { 3 - 6 } & & TNI & Rank & TNI & Rank \\
\hline 1. & Housing & 75.91 & I & 68.19 & I \\
\hline 2. & Breeding & 50.17 & V & 48.79 & III \\
\hline 3. & Feeding and Management & 64.72 & II & 58.11 & II \\
\hline 4. & Health Care & 58.38 & III & 44.72 & V \\
\hline 5. & Marketing and Finance & 57.50 & IV & 49.72 & III \\
\hline
\end{tabular}

Table.2 Knowledge and skill oriented training needs of farm women in minor farm operations

\begin{tabular}{|c|c|c|c|c|c|}
\hline \multirow[t]{2}{*}{ S.No. } & \multirow[t]{2}{*}{ Farm operations } & \multicolumn{2}{|c|}{ Knowledge } & \multicolumn{2}{|c|}{ Skill } \\
\hline & & TNI & Rank & TNI & Rank \\
\hline 1. & $\begin{array}{l}\text { Housing } \\
\text { 1.Construction of scientific low cost cattle shed } \\
\text { 2.Proper design/structure of cattle shed }\end{array}$ & $\begin{array}{l}74.17 \\
66.94\end{array}$ & $\begin{array}{l}\text { I } \\
\text { II }\end{array}$ & $\begin{array}{l}75.00 \\
69.44\end{array}$ & $\begin{array}{l}\text { I } \\
\text { II }\end{array}$ \\
\hline 2. & $\begin{array}{l}\text { Breeding } \\
\text { 1.Selection of breeds } \\
\text { 2.Heat detection } \\
\text { 3.Time of insemination } \\
\text { 4.Maintenance of records on breeding } \\
\text { 5.Time of post-partum insemination }\end{array}$ & $\begin{array}{l}62.50 \\
40.83 \\
42.50 \\
55.28 \\
49.72\end{array}$ & $\begin{array}{c}\text { I } \\
\text { V } \\
\text { IV } \\
\text { II } \\
\text { III }\end{array}$ & $\begin{array}{c}56.94 \\
37.50 \\
- \\
51.94 \\
-\end{array}$ & $\begin{array}{c}\text { I } \\
\text { III } \\
- \\
\text { II } \\
-\end{array}$ \\
\hline 3. & $\begin{array}{l}\text { Feeding and management } \\
\text { 1.Balanced feeding } \\
\text { 2.Care and management of different age groups } \\
\text { 3.Compounding balanced feed using locally available } \\
\text { ingredients } \\
\text { 4.Fodder cultivation } \\
\text { 5.Clean milk production }\end{array}$ & $\begin{array}{l}70.83 \\
48.61 \\
86.94 \\
61.67 \\
55.58\end{array}$ & $\begin{array}{l}\text { II } \\
\text { V } \\
\text { I } \\
\text { III } \\
\text { IV }\end{array}$ & $\begin{array}{l}63.33 \\
55.83 \\
67.50 \\
51.94 \\
51.94\end{array}$ & $\begin{array}{l}\text { II } \\
\text { III } \\
\text { I } \\
\text { IV } \\
\text { III }\end{array}$ \\
\hline 4. & $\begin{array}{l}\text { Health care } \\
\text { 1.Deworming } \\
\text { 2.Vaccination } \\
\text { 3.Control of ectoparasites } \\
\text { 4.Identification and isolation of sick animals } \\
\text { 5.Symptoms of common diseases }\end{array}$ & $\begin{array}{l}61.94 \\
75.00 \\
44.72 \\
51.11 \\
59.17\end{array}$ & $\begin{array}{c}\text { II } \\
\text { I } \\
\text { V } \\
\text { IV } \\
\text { III }\end{array}$ & $\begin{array}{c}- \\
- \\
40.28 \\
46.67 \\
47.22\end{array}$ & $\begin{array}{c}- \\
- \\
\text { III } \\
\text { II } \\
\text { I }\end{array}$ \\
\hline 5. & $\begin{array}{l}\text { Marketing and finance } \\
\text { 1.Banking and insurance } \\
\text { 2.Marketing of livestock and livestock products }\end{array}$ & $\begin{array}{l}60.83 \\
54.17\end{array}$ & $\begin{array}{l}\text { I } \\
\text { II }\end{array}$ & $\begin{array}{l}52.50 \\
46.94\end{array}$ & $\begin{array}{c}1 \\
11\end{array}$ \\
\hline
\end{tabular}

With regard to the training need under breeding, selection of breeds ranked first for both knowledge and skill oriented training needs. The farm women might have perceived, selecting a suitable breed as one of the primary factors in achieving productivity in dairy animals. This finding is in line with those of Fulzele and Meena (1995) who reported that selection of breed was a most needed area of training and Raju et al., (1999) who reported that selection of animals was one of the most needed areas of training. 
As for feeding and management, it was observed that the highest training need for both knowledge and skill was for compounding balanced feed using locally available ingredients. The high cost of concentrates might have compelled the farm women to know and learn the mixing of locally available ingredients which in turn would reduce the feed cost.

The result obtained in the present study is in line with that of Das and Mishra (2002). Regarding health care, vaccination was ranked first for knowledge need and symptoms of common diseases with respect to skill need. The farm women might have been interested to know about the control and identification of important diseases.

The results are inpar with the findings of Fulzele and Meena (1995), Raju et al., (1999), Lalitha and Seethalakshmi (1999), Sujaths and Nanjaiyan (1999), Umarani and Thangamani (2000), Das and Mishra (2002) and Gupta and Tripathi (2002). About the training need with respect to the minor operations of marketing and finance, the farm women needed training the most in banking and insurance for both knowledge and skill. This might be because the farm women had limited information regarding the various sources from which they could obtain financial assistance and also about the insurance policies. This finding is in line with that of Raju et al., (1999).

\section{Implications}

There is a need for conducting more number of need based and well-tailored training programmes suited to farm women which would in turn help them to have more extension agency contacts. Farm operations related to housing should be given top priority in the curriculum of training programmes.

\section{References}

Das, L. and Mishra, S.K. (2002): Training needs of tribal women in farm and home activities. Agricultural Ext. Rev. 14(2): 36.

Fulzele, R.M. and Meena, B.L. (1995): Training needs of dairy tribal women. Indian $J$. Dairy Sci. 48(19): 551-553.

Gupta, M. and Tripathi, H. (2002): Assessment of training needs of rural women in dairy enterprise. Indian J. Dairy Sci. 55(3): 178-182.

Lalitha, N and Seethalakshmi, M. (1999): Rural women in dairy enterprise. The role of institutional intervention. $J$. of Ext. and Res. 1 (2): 121-131.

Madivanane, S. (1990): A study on training needs of farm women in Karaikal region of Pondicherry. Unpublished M.Sc. (agri) thesis, Tamil Nadu Agricultural University, Coimbatore, $202 \mathrm{p}$.

Raju, L.D., Nataraju, M.S. and Niranjan, M. (1999): Women in animal production an ex-post-facto analysis. Agricultural Ext. Rev. 11(3): 3-8.

Sujaths, J. and Nanjaiyan, K. (1999): Gender analysis of time utilization pattern, training needs and problemsof farmers and farm women in farming systems. J.Ext. Edu. 10(1): 2299-2304.

Sumathi, P. and Alagesan, V. (2001): Training need of farm women in integrated farming system. J. Ext. Edu. 11(4): 29722973.

Umarani, K. and Thangamani, K. (2000): Technological needs of women in dairying. J. Ext. Edu. 11(2): 2812-2814.

\section{How to cite this article:}

Bacchu Singh, Deepa Indoria, K. C. Meena and Meena, G. S. 2020. Training Needs of Tribal Farm Women in Dairy Farming in Eastern Rajasthan. Int.J.Curr.Microbiol.App.Sci. 9(05): 3302-3305. doi: https://doi.org/10.20546/ijcmas.2020.905.392 